\title{
Desain Instrumen Pengujian Usabilitas Aplikasi Menggunakan Heuristic Usability Nielson
}

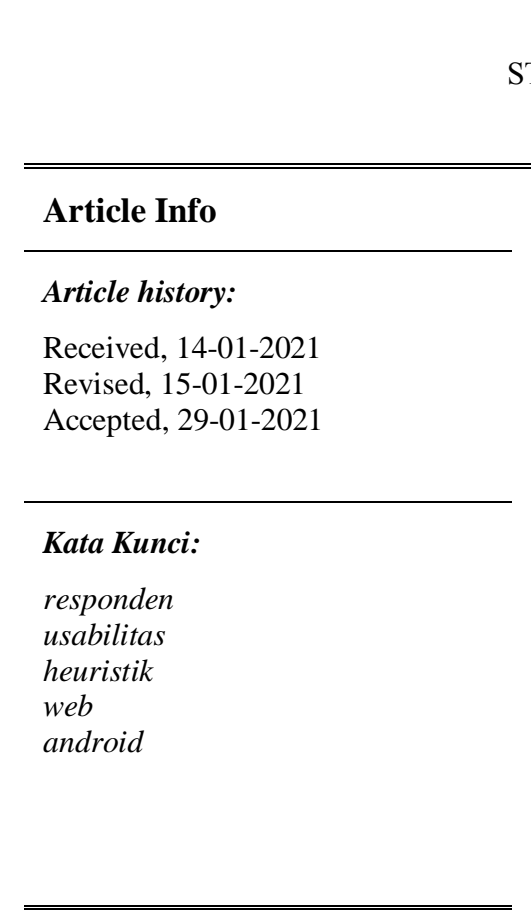

\section{Keywords:}

respondent usability

heuristic

web

android
Febria Sri Handayani

STMIK PalComTech, Palembang, Indonesia febria_sri@palcomtech.ac.id;

\begin{abstract}
ABSTRAK
Kuesioner bagi pengguna akhir merupakan salah satu alat yang dapat digunakan sebagai instrumen survei pengujian usabilitas aplikasi. Identifikasi atribut usabilitas dalam kuesioner dapat dirancang berdasarkan standar ataupun model kualitas perangkat lunak. Salah satunya adalah model kualitas heuristik usabilitas Nielson. Desain kuesioner sebagai instrumen survei pengujian usabilitas aplikasi ini menghasilkan 22 butir atribut usabilitas dan pertanyaan yang dirumuskan dengan menyesuaikan 10 karakteristik model heuristik usabilitas Nielson dengan karakteristik ataupun komponen dasar aplikasi yang akan diuji usabilitasnya. Adapun 10 karakteristik model heuristik usabilitas Nielson tersebut diantaranya (1) Visibility of System Status, (2) Match Between the System and the Real World, (3) User Control and Freedom, (4) Consistency and Standards, (5) Error Prevention, (6) Recognition vs Recall in User Interfaces, (7) Flexibility and Efficiency of Use, (8) Aesthetic and Minimalist Desain, (9) Help Users Recognize, Diagnose and Recover from Errors, (10) Help and Documentation. Desain instrumen ini dapat dikembangkan lagi dan diaplikasikan sebagai pedoman perancangan alat ukur pengujian usabilitas aplikasi baik berbasis web maupun android.
\end{abstract}

\begin{abstract}
The questionnaire for the end user is one tool that can be used as a survey instrument application reusability testing. Identify the usability attributes in the questionnaire can be designed based on software quality standards or models. Wrong one is the Nielson reusability heuristic quality model. Questionnaire design as survey instrument reusability testing of this application produces 22 items of reusability and attributes questions are formulated by adjusting the 10 characteristics of the heuristic model Nielson reusability with the characteristics or basic components of the application to be tested reusability. The 10 characteristics of the Nielson reusability heuristic model including (1) Visibility of System Status, (2) Match Between the System and the Real World, (3) User Control and Freedom, (4) Consistency and Standards, (5) Error Prevention, (6) Recognition vs Recall in User Interfaces, (7) Flexibility and Efficiency of Use, (8) Aesthetic and Minimalist Design, (9) Help Users Recognize, Diagnose and Recover from Errors, (10) Help and Documentation. The design of this instrument can be expanded again and applied as a guideline for designing a measuring instrument for good application reusability testing web or android based.
\end{abstract}

This is an open access article under the CC BY-SAlicense.

\section{PENDAHULUAN}

Setelah melalui fase desain prototipe dan pengujian blackbox oleh pengembang, sebuah aplikasi akan memasuki fase implementasi. Dimana dalam fase ini, peran serta end-user dibutuhkan. Pada fase ini dapat dilakukan pengujian usabilitas untuk mengetahui kualitas aplikasi dalam hal penggunaannya oleh pengguna (end-user). Hal ini penting dilakukan agar baik pengembang maupun pengguna dapat mengetahui batasan-batasan yang diperlukan guna mengukur kualitas usabilitas aplikasi yang sedang diuji cobakan. Untuk memastikan kualitas perangkat lunak yang memadai, karakteristik kualitas yang relevan harus ditentukan, dengan mempertimbangkan penggunaan produk perangkat lunak yang dimaksud [1]. Dalam rangka untuk membuat evaluasi yang tepat dari perangkat 
JSAI : Journal Scientific and Applied Informatics

Vol. 4, No. 01, Januari 2021, hal. 44 52

E-ISSN: 2614-3054; P-ISSN: 2614-3062, accredited by Kemenristekdikti, Sinta 5

DOI: 10.36085

lunak, karakteristik kualitas yang relevan dari produk perangkat lunak telah diusulkan dalam banyak model kualitas, termasuk standar ISO.

Standar kualitas pengujian usabilitas ini bisa menggunakan beberapa standar atau model kualitas aplikasi, bisa juga menggunakan model kuesioner sebagai alat ukurnya. Adapun beberapa standar / model kualitas yang dimaksud diantaranya ISO 25010, ISO 9126, ISO 9241, model usabilitas Nielson, model usabilitas Palmer, model user satisfaction Green-Pearson, dan beberapa model kualitas lainnya [1][2][3]. Sedangkan model kuesioner yang dimaksud diantaranya model kuesioner System Usability Scale (SUS), dan User Experience Questionnaire (UEQ).

Pengujian usabilitas (usability testing) merupakan bagian penting dalam proses desain yang berorientasi pada pengguna. Dengan menggunakan pengujian usabilitas ini, pengembang aplikasi dapat melihat berhasil atau tidaknya desain aplikasi yang telah dihasilkan. Dalam mendesain instrumen pengujian usabilitas, peneliti menggunakan model heuristik usabilitas yang digagas oleh Nielson [3][4][5]. Peneliti menggunakan beberapa publikasi penelitian yang juga membahas desain kuesioner sebagai instrumen pengukuran kualitas perangkat lunak dan model heuristik usabilitas sebagai bahan penelitian terdahulu. Salah satunya penelitian tentang konstruksi dan evaluasi kuesioner user experience[6]. Penelitian ini menghasilkan rancangan kuesioner yang dapat digunakan untuk mengukur pengalaman pengguna produk software berdasarkan faktor daya tarik, perspicuity, efisiensi, keandalan, stimulasi, dan kebaruan dari produk software yang digunakan. .

\section{METODE PENELITIAN}

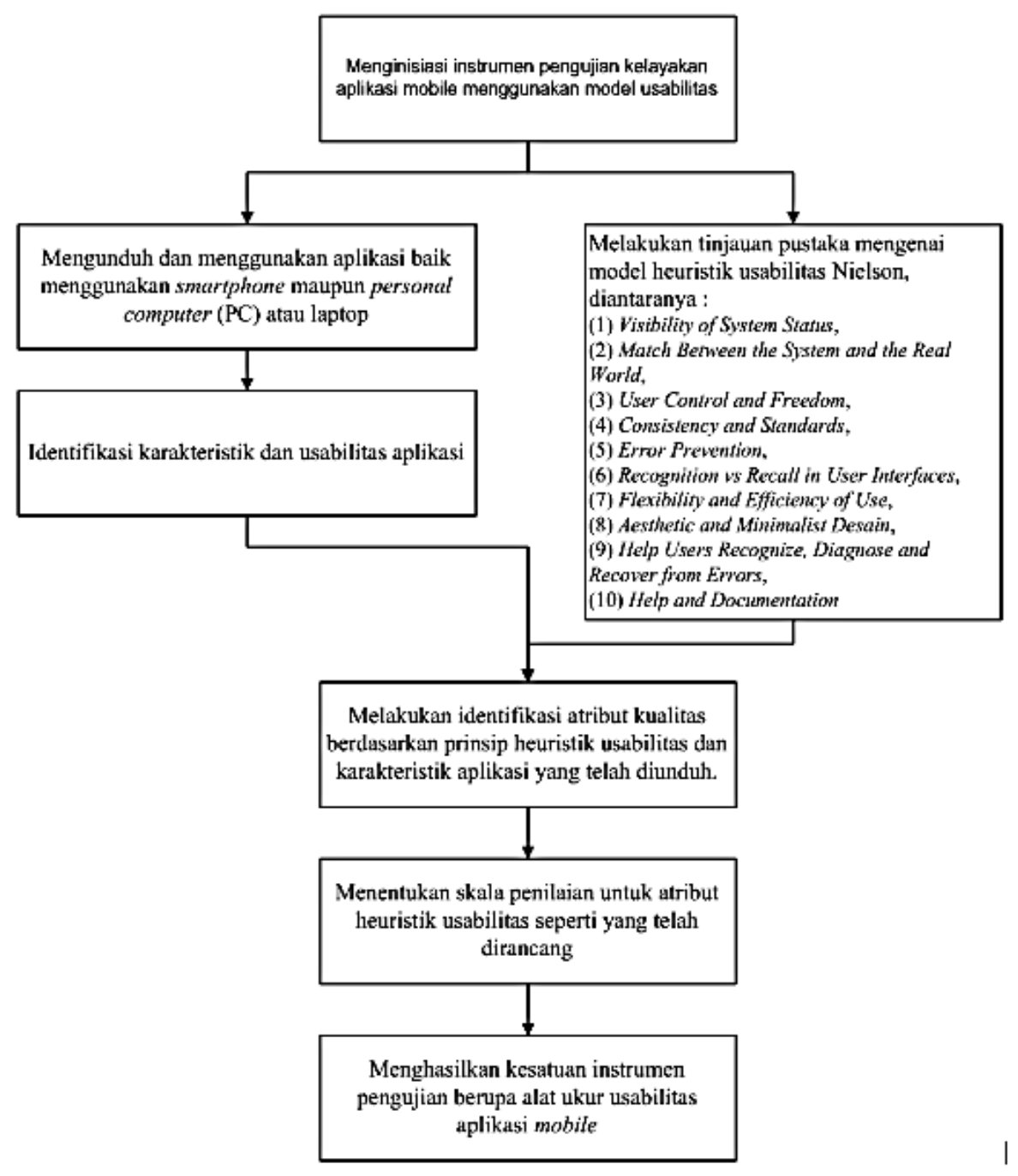

Gambar 1. Alur Penelitian 
Langkah-langkah yang dilakukan dalam mendesain instrumen dan sampling pengujian usabilitas dapat dilihat pada gambar 1, diantaranya:

1. Mengunduh dan menggunakan aplikasi baik menggunakan smartphone maupun personal computer (PC) atau laptop. Hal ini dilakukan untuk mengidentifikasi karakteristik aplikasi dan melakukan perbandingan usabilitasnya.

2. Melakukan tinjauan pustaka mengenai model heuristik usabilitas Nielson.

3. Melakukan identifikasi atribut kualitas berdasarkan prinsip heuristik usabilitas dan karakteristik aplikasi yang telah diunduh pada langkah nomor 1 .

4. Menentukan skala penilaian untuk atribut heuristik usabilitas seperti yang telah dirancang pada nomor 3 .

\section{HASIL DAN ANALISIS}

Usabilitas atau istilah lainnya kebergunaan merupakan metode pengujian dan pengukuran aplikasi dilihat dari segi kemudahan dalam mempelajari cara menggunakan aplikasi (learnability), seberapa cepat aplikasi dapat membantu pengguna dalam menyelesaikan pekerjaannya (efficiency), sejauh mana pengguna dapat mengingat tampilan atau komponen pada aplikasi (memorability), cara mengetahui kesalahan yang dilakukan pada aplikasi dan cara mengatasinya (errors), dan kepuasan pengguna selama menggunakan aplikasi (satisfaction) [5][7][8].

Padangan mengenai heuristik usabilitas merupakan tinjauan desain interaksi dan usabilitas aplikasi secara umum dan bukan pedoman usabilitas secara spesifik [9][10]. Terdapat 10 karakteristik pada heuristik usabilitas seperti yang dijelaskan pada tabel 1 . Untuk menunjang keberhasilan desain antarmuka dan usabilitas pada aplikasi, maka pengembang aplikasi juga harus mengidentifikasi kebutuhan dan karakteristik penggunanya. Seperti halnya lingkungan sistem, pengguna aplikasi khususnya yang berbasis android tentunya juga harus diidentifikasi mulai dari usia, pekerjaan, kemampuan serta pengetahuan seputar lingkungan sistem dan aplikasinya.

Tabel 1. Prinsip Heuristik Usabilitas Nielson

\begin{tabular}{|l|l|}
\hline \multicolumn{1}{|c|}{ Prinsip } & \multicolumn{1}{c|}{ Keterangan } \\
\hline $\begin{array}{l}\text { Visibility of } \\
\text { system status } \\
\text { (feed back) }\end{array}$ & $\begin{array}{l}\text { Aplikasi memberikan umpan balik kepada pengguna dengan menampilkan } \\
\text { informasi tentang status sistem, baik berupa pesan, konfirmasi akses, ataupun } \\
\text { waktu yang sesuai. Dengan adanya informasi ini tidak hanya akan membuat } \\
\text { pengguna aplikasi tahu kondisi aplikasi yang sedang digunakan tapi juga bisa } \\
\text { mengambil keputusan tentang apa yang seharusnya dilakukan tanpa } \\
\text { mengganggu konsentrasi mereka. }\end{array}$ \\
\hline $\begin{array}{l}\text { Match between } \\
\text { system and the } \\
\text { real world }\end{array}$ & $\begin{array}{l}\text { Aplikasi memiliki kemiripan atau kesamaan perilaku dengan kondisi pengguna } \\
\text { di dunia nyata. Kemiripan tersebut bisa berupa bahasa, kebiasaan, atau bentuk } \\
\text { komponen pada aplikasi yang biasa digunakan oleh pengguna. Persepsi } \\
\text { pengguna dalam menggunakan aplikasi dapat dipengaruhi oleh pengalamannya } \\
\text { dalam menggunakan aplikasi sejenis. Sebagai contoh icon kalkulator, } \\
\text { panggilan telepon, kalender, jam, dan lainnya yang ada pada smartphone } \\
\text { menginisiasi bentuknya di dunia nyata dan mengindikasikannya pada para } \\
\text { pengguna bagaimana icon tersebut harus diperlakukan. }\end{array}$ \\
\hline $\begin{array}{l}\text { Use control and } \\
\text { freedom }\end{array}$ & $\begin{array}{l}\text { Jika terdapat beberapa kekeliruan kecil dalam pemakaian aplikasi, pengguna } \\
\text { mempunyai kendali dan kebebasan dalam mengambil keputusan. Pengguna } \\
\text { aplikasi android bisa menggunakan tombol back yang ada pada bagian bawah } \\
\text { sebelah kanan dari tampilan smartphone untuk kembali ke halaman } \\
\text { sebelumnya. }\end{array}$ \\
\hline
\end{tabular}




\begin{tabular}{|c|c|}
\hline $\begin{array}{l}\text { Consistency } \\
\text { and standards }\end{array}$ & $\begin{array}{l}\text { Aplikasi harus memiliki standar penggunaan dan harus konsisten. Konsistensi } \\
\text { yang harus dijaga bisa dari sisi internal maupun eksternal aplikasi. Seperti } \\
\text { halnya pada WhatsApp floating action icon akan tetap berada pada posisi yang } \\
\text { sama hanya iconnya saja yang berubah-ubah tergantung pada sesi layarnya. } \\
\text { Selain itu, posisi keranjang belanja pada beberapa aplikasi belanja online di } \\
\text { smartphone biasanya ada pada posisi sebelah kanan atas. Konsistensi yang } \\
\text { seperti ini akan memudahkan pengguna dalam mengenali, mengingat, dan } \\
\text { memutuskan harus bagaimana menindaklanjuti-nya. }\end{array}$ \\
\hline $\begin{array}{l}\text { Error } \\
\text { prevention }\end{array}$ & $\begin{array}{l}\text { Aplikasi memberikan fasilitas untuk mencegah terjadinya kesalahan pemakaian } \\
\text { aplikasi oleh pengguna. Ada } 2 \text { jenis kesalahan (error) yatu Slips dan Mistakes } \\
\text { [11]. Dimana Slips merupakan sebuah kesalahan yang terjadi ketika pengguna } \\
\text { ingin melakukan aksi tapi malah menimbulkan aksi yang lain dan mungkin } \\
\text { tidak diinginkannya. Seperti seringnya kita salah ketik (typo) saat chatting di } \\
\text { smartphone. Sedangkan Mistakes merupakan kesalahan yang terjadi saat } \\
\text { pengguna aplikasi mendapatkan informasi yang salah tentang aksi yang } \\
\text { dilakukannya. Misalnya saat pengguna tidak sengaja menekan tombol delete } \\
\text { yang menyebabkan beberapa teks terhapus. Hal ini bisa dihindari dengan } \\
\text { diberikannya fitur pengingat sebagai konfirmasi atas aksi delete yang } \\
\text { dilakukannya baik itu sengaja ataupun tidak sengaja. }\end{array}$ \\
\hline $\begin{array}{l}\text { Recoqnation } \\
\text { rather than } \\
\text { recall }\end{array}$ & $\begin{array}{l}\text { Aplikasi seharusnya memiliki ciri-ciri yang unik tapi sederhana sehingga dapat } \\
\text { membantu pengguna dalam mengenali, mendiagnosa, dan mengatasi masalah. } \\
\text { Misalnya jika ingin kembali ke halaman sebelumnya, user bisa diberi pilihan } \\
\text { untuk mengklik tombol back atau bisa memilih dari bagian navigasi sehingga } \\
\text { tidak harus mengingat tadi atau sebelumnya ada dihalaman apa. }\end{array}$ \\
\hline $\begin{array}{l}\text { Flexibility and } \\
\text { efficient of use }\end{array}$ & $\begin{array}{l}\text { Dalam pemakaiannya, aplikasi harus fleksibel dan efisien dalam hal sumber } \\
\text { daya sehingga dapat mengakomodasi antara pengguna yang ahli dan pengguna } \\
\text { pemula. Salah satu contohnya adalah penggunaan akselarator sebagai fitur user } \\
\text { interface (UI) untuk mempercepat proses ataupun interaksi pada aplikasi. Para } \\
\text { pengguna yang sudah ahli bisa menggunakan semacam shortcut seperti } \\
\text { menekan satu kata dalam beberapa detik lalu menggesernya untuk memblok } \\
\text { satu dan beberapa teks lainnya tanpa harus menggunakan pointer mouse untuk } \\
\text { memblok teks tersebut seperti yang bisa dilakukan oleh pengguna baru. }\end{array}$ \\
\hline $\begin{array}{l}\text { Aesthetic and } \\
\text { minimalist } \\
\text { design }\end{array}$ & $\begin{array}{l}\text { Aplikasi harus dirancang secara sederhana dan memiliki tampilan yang } \\
\text { menarik, sehingga mendukung prinsip Recoqnation rather than recall bagi } \\
\text { penggunanya. Konten dan desain visual pada antarmuka harus tetap fokus dan } \\
\text { merepresentasikan rasio dari informasi mulai dari yang relevan sampai yang } \\
\text { tidak relevan. Setiap elemen tambahan seperti gambar, teks, grafik, dan lainnya } \\
\text { harus mendukung proses dan kebutuhan pengguna. }\end{array}$ \\
\hline $\begin{array}{l}\text { Help users } \\
\text { recoqnize, } \\
\text { dialogue, and } \\
\text { recovers from } \\
\text { errors }\end{array}$ & $\begin{array}{l}\text { Aplikasi harus dapat memberikan bantuan bagi pengguna dalam mengenali, } \\
\text { berdialog, dan memperbaiki beberapa kesalahan. Usahakan untuk } \\
\text { menyampaikan informasi kesalahan dengan jelas dan disertai dengan solusi } \\
\text { cara memperbaiki kesalahan tersebut. Misalnya untuk fitur pencarian dengan } \\
\text { filter tertentu, jika informasi yang dicari tidak ditemukan, maka seharusnya } \\
\text { disediakan tombol untuk mereset filter pencarian tersebut. }\end{array}$ \\
\hline $\begin{array}{l}\text { Help and } \\
\text { documentation }\end{array}$ & $\begin{array}{l}\text { Aplikasi memiliki fasilitas dokumentasi yang relevan serta fitur bantuan yang } \\
\text { baik bagi penggunanya. Hal ini tentunya akan berguna bagi pengguna baru. } \\
\text { Beberapa bantuan yang dimaksud seperti tooltips pada icon atau tombol, } \\
\text { popover pada link, contextual information pada fitur pencarian, dan lain } \\
\text { sebagainya. }\end{array}$ \\
\hline
\end{tabular}


Beberapa aplikasi khususnya yang berbasis android yang beredar sekarang dapat pula diakses pada versi website. Aplikasi yang seperti ini bertujuan untuk lebih mengutamakan portabilitas dan kenyamanan pengguna dalam mengakses aplikasi guna membantu pekerjaan sehari-hari ataupun sekedar menyalurkan hobi seperti halnya mobile game atau aplikasi media sosial (medsos). Dengan menggunakan smartphone, para pengguna dapat mengunduh aplikasi tersebut melalui fasilitas google play atau play store. Untuk dapat menggunakan aplikasi tersebut, para pengguna sebaiknya membaca terlebih dahulu petunjuk penggunaan aplikasi seperti yang informasi yang tertera pada detil aplikasi yang dipilih pada fasilitas google play, baru kemudian mengunduhnya. Hal ini dilakukan agar pada saat mulai menggunakan aplikasi, minimal pengguna telah mengenali beberapa karakteristik dasar aplikasi. Tabel 2 menjelaskan lingkungan sistem dari beberapa aplikasi sejenis yang dapat dikategorikan kedalam bentuk karakteristik dasar aplikasi.

Tabel 2. Lingkungan Sistem

\begin{tabular}{|l|l|}
\hline $\begin{array}{c}\text { Karakteristik } \\
\text { Perangkat }\end{array}$ & \multicolumn{1}{c|}{ Spesifikasi } \\
\hline Perangkat keras & $\begin{array}{l}\text { - Smartphone, minimal RAM 1GB dan layar 4,7 inci. } \\
\text { - PC/Laptop, minimal RAM 1GB dan layar 14 inci. }\end{array}$ \\
\hline Sistem operasi & $\begin{array}{l}\text { - Android minimal versi 4.0 ice cream. } \\
\text { - Windows minimal versi 7. }\end{array}$ \\
\hline $\begin{array}{l}\text { Kebutuhan } \\
\text { akses lainnya }\end{array}$ & $\begin{array}{l}\text { - Koneksi internet (hotspot/wifi). } \\
\text { - Aplikasi google play atau play store. }\end{array}$ \\
\hline
\end{tabular}

\subsection{Desain Atribut Kualitas}

Untuk membuat instrumen pengujian usabilitas aplikasi, tidak cukup hanya memahami maksud dari setiap karakteristik heuristik usabilitas. Akan tetapi tim penguji juga harus mempelajari lebih dalam mengenai karakteristik aplikasi yang akan diuji. Setelah mempelajari keduanya, maka dapat dirancang beberapa atribut kualitas aplikasi. Atribut kualitas yang dimaksud dirancang berdasarkan karakteristik heuristik usabilitas Nielson dan tentunya juga disesuaikan dengan karakteristik aplikasi. Hal ini dilakukan untuk memastikan beberapa atribut kualitas tersebut memang benar-benar diterima dan dipahami oleh para responden. Atribut kualitas yang telah dirancang dapat dijadikan pedoman untuk membuat pertanyaan/pernyataan seputar usabilitas aplikasi. Dimana setiap pertanyaan/pernyataan tersebut akan disertai dengan skala penilaian pilihan jawaban responden. Dari skala penilaian inilah peneliti ataupun pengembang aplikasi dapat mengukur keberhasilan desain antarmuka dan kualitas usabilitas aplikasi. Adapun rancangan atribut kualitas dan pertanyaan yang telah disesuaikan dengan heuristik usabilitas dan karakteristik aplikasi dapat dilihat pada tabel 3 .

Tabel 3. Rancangan Atribut Kualitas Dan Pertanyaan Dalam Kuesioner

\begin{tabular}{|c|c|c|c|c|c|c|}
\hline \multirow{2}{*}{ Prinsip } & \multirow{2}{*}{ Atribut Kualitas } & \multirow{2}{*}{ Pertanyaan } & \multicolumn{4}{|c|}{ Skor } \\
\hline & & & 1 & 2 & 3 & 4 \\
\hline $\begin{array}{l}\text { Visibility of } \\
\text { system status } \\
\text { (feed back) }\end{array}$ & $\begin{array}{l}\text { - Navigasi } \\
\text { - Konfirmasi akses } \\
\text { aplikasi } \\
\text { - Pewarnaan }\end{array}$ & $\begin{array}{l}\text { - Menurut anda, apakah navigasi pada } \\
\text { aplikasi ini mudah dipahami? } \\
\text { - Apakah aplikasi memberikan } \\
\text { konfirmasi kepada anda mengenai } \\
\text { proses downloading info yang anda } \\
\text { lakukan? } \\
\text { - Apakah teknik pewarnaan pada } \\
\text { tampilan aplikasi ini tidak } \\
\text { membosankan? }\end{array}$ & & & & \\
\hline
\end{tabular}




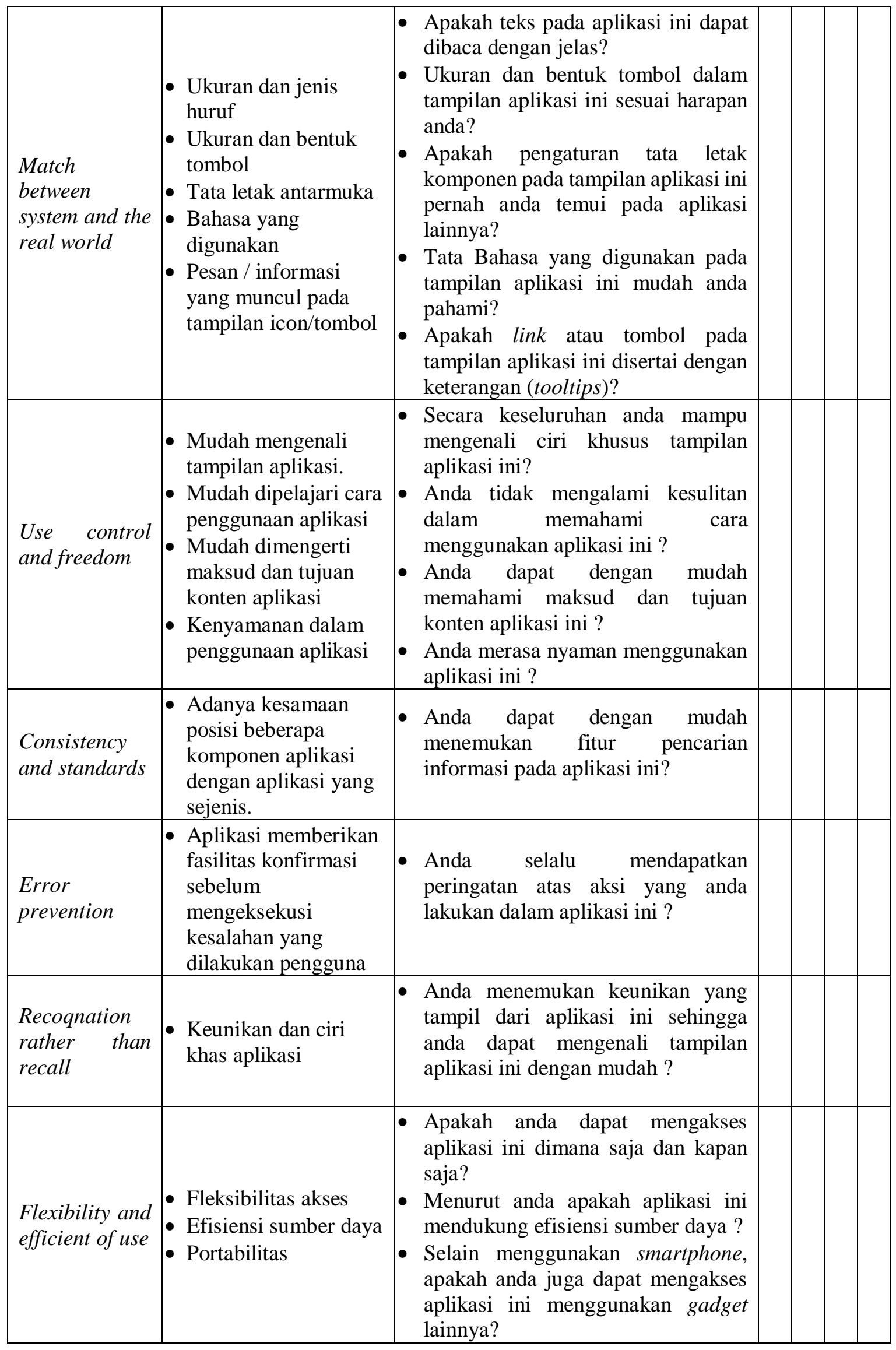


JSAI : Journal Scientific and Applied Informatics

Vol. 4, No. 01, Januari 2021, hal. 44 52

E-ISSN: 2614-3054; P-ISSN: 2614-3062, accredited by Kemenristekdikti, Sinta 5

DOI: 10.36085

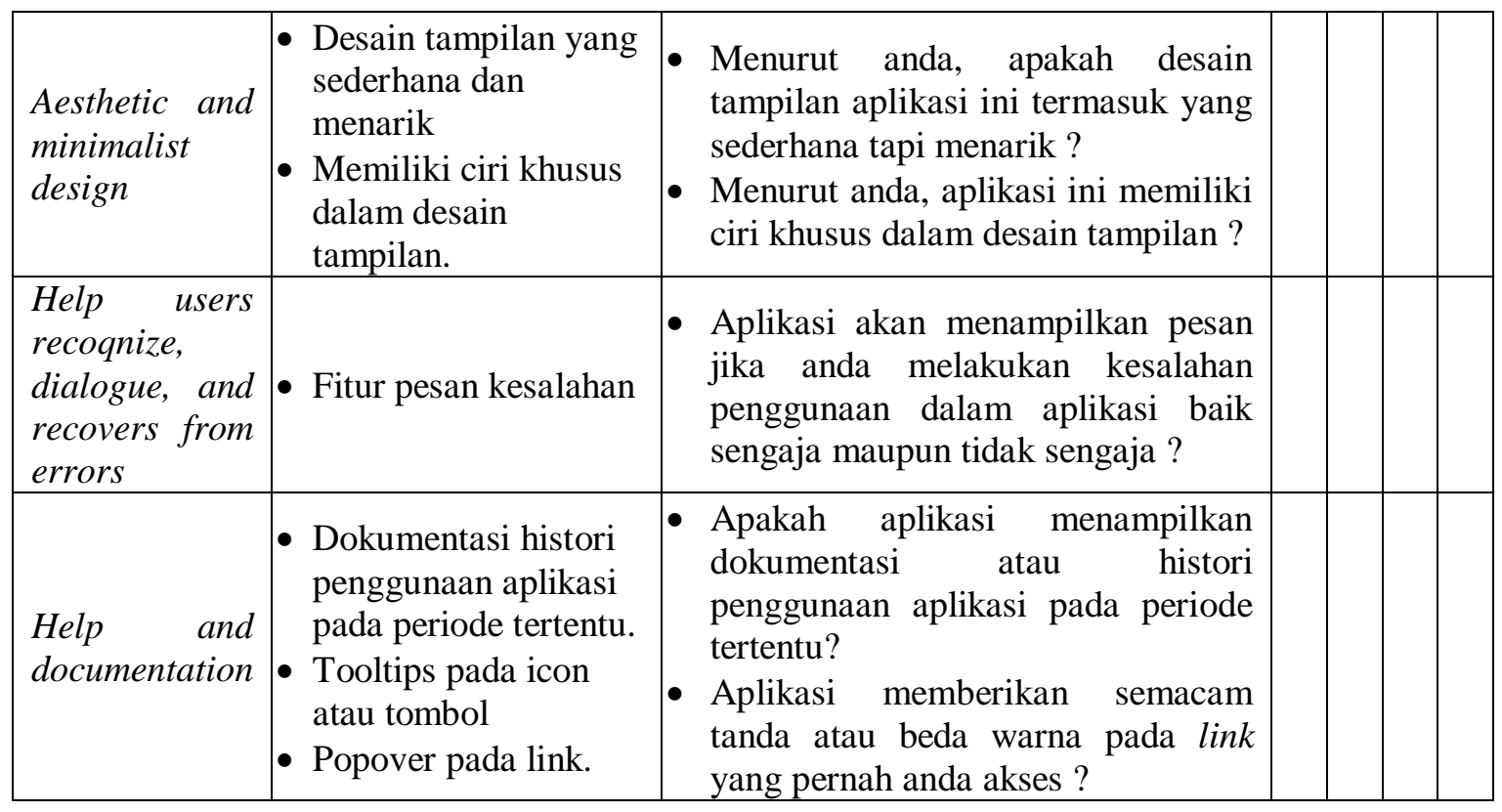

Daftar penyataan dan pertanyaan diatas, peneliti juga dapat menambahkan beberapa pertanyaan uraian yang berkaitan dengan indikator yang ditanyakan. Pertanyaan uraian ini diperlukan selain untuk memahami alasan pemilihan jawaban responden, dapat juga digunakan sebagai media untuk mendukung opini peneliti yang secara tidak langsung adalah juga sebagai pengguna aplikasi.

\subsection{Skala Pengukuran}

Beberapa jenis skala pengukuran dapat digunakan untuk memberi skor pilihan jawaban responden. Akan tetapi seperti yang ditampilkan pada tabel 3, digunakan skala Likert dengan 4 pilihan jawaban[12]. Masing-masing pilihan jawaban akan diberi skor mulai dari 1 untuk yang paling rendah sampai 4 untuk yang paling tinggi. Angka nilai ini penting untuk memberi batasan ekspektasi penilaian masing-masing responden. Besaran angka nilai untuk masing-masing pilihan jawaban juga tergantung pada tipe kalimat pertanyaan/pernyataan, apakah termasuk kalimat positif atau negatif. Misalnya untuk menyatakan sebuah persetujuan, responden bisa memilih pilihan jawaban sangat tidak setuju (skor $=1$ (kalimat positif) $/ 4$ (kalimat negatif)), tidak setuju (skor $=2$ (kalimat positif) / 3 (kalimat negatif)), setuju (skor $=3$ (kalimat positif) / 2 (kalimat negatif)), atau sangat setuju (skor=4 (kalimat positif) / 1 (kalimat negatif)).

\section{KESIMPULAN}

Desain instrumen pengujian usabilitas aplikasi ini dirancang berdasarkan model heuristik usabilitas Nielson dan juga berdasarkan karakteristik aplikasi baik yang berbasis android maupun yang berbasis web. Hasil perancangan terdiri dari 22 butir atribut kualitas dan pertanyaan yang saling terkait. Hasil dari perancangan ini dapat diimplementasikan pada rencana pengujian dan pengukuran kualitas aplikasi dari segi usabilitasnya secara heuristik.

\section{UCAPAN TERIMA KASIH}

Ucapan terima kasih yang sebesar-besarnya penulis ucapkan kepada dewan redaksi Jurnal Scientific and Applied Informatics (JSAI) Universitas Muhammadiyah Bengkulu yang telah membantu untuk proses publikasi naskah jurnal ini. Ucapan yang sama juga disampaikan untuk Lembaga Penelitian dan Pengabdian Kepada Masyarakat (LPPM) STMIK PalComTech Palembang atas bantuannya membimbing dan mengarahkan penulis dalam hal penelitian dan publikasinya. 


\section{REFERENSI}

[1] J. M. S. França and M. S. Soares, "SOAQM: Quality model for SOA applications based on ISO 25010," in ICEIS 2015 - 17th International Conference on Enterprise Information Systems, Proceedings, 2015, vol. 2, doi: 10.5220/0005369100600070.

[2] J. P. Miguel, D. Mauricio, and G. Rodríguez, "A Review of Software Quality Models for the Evaluation of Software Products," Int. J. Softw. Eng. Appl., vol. 5, no. 6, 2014, doi: 10.5121/ijsea.2014.5603.

[3] R. Firmansyah, "Evaluasi Heuristik Pada Desain Interface Aplikasi My Indihome," Semin. Nas. Ilmu Pengetah. dan Teknol. Komput., 2016.

[4] N. 93, "10 Usability Heuristics for User Interface Design," Conf. companion Hum. factors Comput. Syst. CHI 94, 2005.

[5] J. Nielsen, "Usability 101 : Introduction to Usability Why Usability is Important," Usabilty 101introduction to usabilty, vol. 266, 2012.

[6] B. Laugwitz, T. Held, and M. Schrepp, "Construction and evaluation of a user experience questionnaire," in Lecture Notes in Computer Science (including subseries Lecture Notes in Artificial Intelligence and Lecture Notes in Bioinformatics), 2008, vol. 5298 LNCS, doi: 10.1007/978-3-54089350-9_6.

[7] J. Nielsen, "10 Usability Heuristics for User Interface Design," Conference companion on Human factors in computing systems CHI 94. 1995.

[8] U. Ependi, "HEURISTIC EVALUATION FOR MOBILE APPLICATION (STUDI KASUS: APLIKASI DEPO AUTO 2000 TANJUNG API API PALEMBANG)," Simetris J. Tek. Mesin, Elektro dan Ilmu Komput., vol. 8, no. 2, 2017, doi: 10.24176/simet.v8i2.1525.

[9] J. Nielsen, "Usability 101: Introduction to Usability," All Usability, 2012.

[10] N. Moraveji and C. Soesanto, "Towards stress-less user interfaces: 10 Design Heuristics Based on the Psychophysiology of Stress," Proc. 2012 ACM Annu. Conf. Ext. Abstr. Hum. Factors Comput. Syst. Ext. Abstr. - CHI EA '12, 2012.

[11] D. Norman, The Design of Everyday Things: Revised \& Expanded Edition. 2013.

[12] H. Sarjono and W. Julianita, "SPSS vs LISREL: sebuah pengantar, aplikasi untuk riset," Jakarta: Salemba Empat, 2011. 